\title{
Postcolonial partnerships: deep sea research, media coverage and (inter)national narratives on the Galathea Deep Sea Expedition from 1950 to 1952
}

\author{
KRISTIAN HVIDTFELT NIELSEN*
}

\begin{abstract}
The Danish Galathea Deep Sea Expedition between 1950 and 1952 combined scientific and official objectives with the production of national and international narratives distributed through the daily press and other media. Dispatched by the Danish government on a newly acquired naval ship, the expedition undertook groundbreaking deep sea research while also devoting efforts to showing the flag, public communication of science, and international cooperation. The expedition was conceived after the war as a way in which to rehabilitate Denmark's reputation internationally and to rebuild national pride. To this end, the expedition included an onboard press section reporting the expedition to the Danish public and to an international audience. The press section mediated the favourable, post-war and postcolonial image of Denmark as an internationalist, scientific, modernizing and civilizing nation for which the expedition planners and many others were hoping. The expedition, therefore, was highly relevant to, indeed fed on, the emerging internationalist agenda in Denmark's foreign policy. Bringing out these aspects of the historical context of the expedition, this paper adds important perspectives to our knowledge about the expedition in particular and, more generally, about scientific exploration in the immediate post-war and postcolonial period.
\end{abstract}

In their introduction to the anthology Narrating the Arctic, Michael Bravo and Sverker Sörlin argue for studying narratives as an important part of scientific practice. ${ }^{1}$ They say that scientific knowledge needs narratives to travel. Narratives about science, nations, empires and peoples are fundamental for scientists' establishment of the institutional infrastructure that enables scientific knowledge to acquire more than local acceptance. Like other means of material and cultural support for scientific endeavours, narratives are technologies of travel facilitating the movement, transmission and translation of observations, specimens, papers, books and instruments. The narratives that

\footnotetext{
" Department of Science Studies, Aarhus University, C. F. Møllers Allé, Building 1110, DK-8000 Århus C, Denmark. Email: khn@ivs.au.dk.

Research for this article was funded by the Danish Council for Independent Research, Humanities. I would like to thank Casper Andersen (Aarhus University), the anonymous referees and Simon Schaffer for suggestions and comments. Special thanks go to Associate Professor Emeritus Torben Wolff, Zoological Museum, University of Copenhagen. A previous version of this paper was presented at the Annual Meeting of the History of Science Society, Vancouver, 2-5 November 2006.

1 M. Bravo and S. Sörlin, 'Narrative and practice: an introduction', in Narrating the Arctic: A Cultural History of Nordic Scientific Practices (ed. M. Bravo and S. Sörlin), Canton, MA, 2002, 3-32.
} 
accompany particular scientific undertakings may be understood as discursive spaces allowing for the production and circulation of certain kinds of scientific knowledge.

This paper traces the historical context of scientific and (inter)national narratives related to the Danish Galathea Deep Sea Expedition between 1950 and 1952. Combining scientific goals with national interests on an expedition was nothing new. Numerous studies of colonial science have shown how, in many different ways and not always as a mere servant to colonialism, the pursuit of science has been related to the enactment of colonial power. ${ }^{2}$ As a Danish example from the twentieth century, the geologist and explorer Lauge Koch relied on Denmark's geopolitical stake in East Greenland to stage several expeditions, most notably the Three-Year Expedition to East Greenland from 1931 to 1934 . The case of Koch clearly demonstrates that the state of Denmark benefited from Koch's explorations, referred to by Prime Minister Thorvald Stauning as 'the scientific occupation' of East Greenland. At the International Court in The Hague in 1933, Koch's results helped settle in Danish favour the territorial controversy about Northeast Greenland that had emerged between Denmark and Norway during the late 1920s and early 1930s. The case also brings out the advantages of government support enjoyed by Koch in his rather costly modernization of Arctic exploration. $^{3}$

The novelty of the Danish Galathea Deep Sea Expedition, therefore, lies not so much in its combination of scientific endeavours with national aims, but in the strategic role played by the press section of the expedition in mediating narratives about (Danish) scientific exploration and about Denmark the nation, its national history and its national identity. ${ }^{4}$ To be sure, the expedition was a pioneering effort in bringing together under the same (ship's) roof scientists, naval officers and conscripts, plus a small crew of journalists and photographers. The press, information or publicity section, as it was variously called, produced press releases, regular articles for the daily press and weeklies, and educational films to be used in schools and in the public film lectures that were very much in demand at the time, before television made its way into Danish homes. The press section also produced thousands of photographs, some used by scientists as documentation and some in popularization. One way or another, many of these materials blended narratives about the scientific research of the expedition with narratives about Denmark, Danish history and Danish identity. These were technologies of travel enabling the expedition and its results to become widely known while under way.

2 R. MacLeod (ed.), Nature and Empire: Science and the Colonial Enterprise, Osiris (2000), 15; L. Schiebinger, M. Harrison, J. Cañizares-Esguerra, S. H. Harris and M. A. Osborne, 'Focus: colonial science', Isis (2005), 96, 52-87; N. Reingold and M. Rothenberg (eds.), Scientific Colonialism: A Cross-cultural Comparison, Washington, DC, 1987; D. P. Miller and P. H. Reill (eds.), Visions of Empire: Voyages, Botany and Representations of Nature, Cambridge, 1996.

3 The Koch case is presented in C. J. Ries, 'Lauge Koch and the mapping of North East Greenland: tradition and modernity in Danish arctic research, 1920-1940', in Narrating the Arctic: A Cultural History of Nordic Scientific Practices (ed. M. Bravo and S. Sörlin), Canton, MA, 2002, 199-231; and C. J. Ries, Retten, magten og ceren: Lauge Koch-sagen - en strid om Grønlands geologiske udforskning, Copenhagen, 2003.

4 K. H. Nielsen, 'In quest of publicity: the science-media partnership of the Galathea Deep Sea Expedition from 1950 to 1952 ', Public Understanding of Science, in press. 
The expedition took place at a moment when Denmark had already lost its small trade colonies in Africa, India and the West Indies, when Denmark's only colonial ambitions involved Greenland and the Faroe Islands, and when decolonization efforts were initiated in many other places in the world. More than simply an early event in the era of postcolonialism, however, the expedition did not imply the end of Western expansion. Rather, it may be seen as an attempt to reconceptualize Denmark's ambitions in the new world situation after the war. The period saw the rise of international networks of development and cooperation and an increased growth in international media. The expedition was an attempt to place Denmark in this emerging global community as a small yet important nation, technologically as well as scientifically advanced. It could be argued that the partnership between deep sea research, media coverage and (inter)national narratives undergirding the expedition was an early instance of what Gabrielle Hecht, Warwick Anderson and others have called 'postcolonial technoscience'. Admittedly and aptly for a small nation such as Denmark, the expedition was a small example of such postcolonial technoscience. ${ }^{5}$

The expedition was postcolonial in several ways. Oceanographic deep sea research was closely linked to extensive media coverage, including narratives about Denmark's exploration history and Denmark's particular experiences of colonialism. The national narratives of the expedition concerned rebuilding national self-esteem after the war rather than building or extending an empire. The expedition's main audience comprised Danes at home and abroad. In effect, by means of the media the expedition's narrative told the proud story of how Danish national identity and Danish exploratory science were linked together by tradition and by nationality. The postimperial intentions of the expedition related to positioning Denmark in the global network of technoscientific knowledge production and reconstructing Denmark's image in the global media world. Thus the expedition devoted much effort to international, scientific collaboration and to entertaining local media in every port visited.

This paper traces such postcolonial and technoscientific aspects by following the expedition's narratives about Danish oceanic science and the Danish nation. The historical context is provided by the history of Danish national identity, in particular by Denmark's experiences during the Second World War and in the immediate post-war period. The organizers of the expedition struggled with Denmark's international image and national confidence as a result of Danish political and economic collaboration with Nazi Germany throughout the main period of the Second World War. They saw scientific exploration as a way in which to imagine Denmark's national community anew. The national narrative produced by the expedition portrayed Denmark as an open, collaborative, rational and, above all, scientific nation. Like the national narratives discussed by Benedict Anderson, the Danish narrative embedded in the expedition built on historical continuity, heredity and naturalness. ${ }^{6}$ To the organizers, the expedition was a way in which to rise above the years of German dependence while

5 G. Hecht and W. Anderson (eds.), Special issue on postcolonial technoscience, Social Studies of Science (2002), 32.

6 B. Anderson, 'Narrating the nation', Times Literary Supplement, 13 June 1986, 659; and B. Anderson, Imagined Communities: Reflections on the Origin and Spread of Nationalism, rev. edn, London, 2006. 
emphasizing Denmark's historical tradition of exploration and national grandeur. Moreover, Danes, or, more specifically, Danish scientists, almost exclusively had the scientific competence to succeed in such a venture. Finally, embarkation on an oceangoing expedition seemed entirely obvious, due to Denmark's geographical dependence on the sea and Denmark's long history of maritime and naval strength.

It is interesting to note that the expedition's narrative included a kind of postcolonial awareness of Denmark's history as a colonial power. These narratives were mainly quite sentimental about the heyday of Denmark's colonialism and the local consequences of Danish colonial authority. Yet there were also a few critical voices to be heard; these voices were not those of the colonized, but of the colonizer revisiting the colonial past. These are, perhaps, signs of the kind of Danish postcolonial selfflagellation that literary scholar Kirsten Thisted has identified in the Greenland case and that the historical novels of Thorkild Hansen clearly demonstrate in relation to the Danish colonies on the Gold Coast and in the West Indies. ${ }^{7}$ The narratives of the Galathea Expedition, however, are not postcolonial in the sense that they offer a critique of Western science and superiority. There are no Saidian sensitivities of Western Orientalism at play like those found in contemporary Danish literature such as Peter Høeg's Smilla's Sense of Snow. ${ }^{8}$ However, the narratives of the expedition do construct what we may think of as postcolonial exploratory science, scientific research conducted in the field as a tool of national cohesion and international cooperation, partly by means of conquering the attention of the media. According to this narrative, science carried out in non-Western settings is no longer the instrument of empire, if it ever were just that. Instead, it has become the rational objective method with which to ensure non-aggressive binding relations between smaller and greater nations, to reconstruct national pride in an international setting and to communicate scientific results and scientific values to a larger audience by means of the media.

\section{Denmark, the duck pond}

The Ugly Duckling, the nineteenth-century Danish writer Hans Christian Andersen's famous fairy tale, tells the story of a cygnet which, mistaken for a duckling, is ostracized by its fellow barnyard fowls and other animals. The story is a disguised autobiography: Andersen was the ugly duckling bullied and stressed in his youth until at last recognized as an adult for his real qualities as a sublime storyteller. The story is also a scathing selfportrait of Danish provincialism. The freshly hatched ducklings stand awestruck by the size of the world when their mother reveals the mind-boggling truth that 'it extends on and on, clear across to the other side of the garden and right on into the parson's field, though that is further than I have ever been' ${ }^{9}$

7 K. Thisted, 'The power to represent: intertextuality and discourse in Smilla's Sense of Snow', in Narrating the Arctic: A Cultural History of Nordic Scientific Practices (ed. M. Bravo and S. Sörlin), Canton, MA, 2002, 311-42; and M. Stecher-Hansen, History Revisited: Fact and Fiction in Thorkild Hansen's Documentary Works, Columbia, SC, 1997.

8 Thisted, op. cit. (7).

9 H. C. Andersen, The Complete Stories, London, 2005. 
When Andersen published his story in the mid-nineteenth century, Denmark was indeed a small provincial duck pond compared with its former geographical extent and political aspirations. As the historian Uffe Østergaard has noted in several accounts of the peasant roots of Danish modernity, the modern Danish nation state, possessed of a remarkably homogeneous state, nation, people, language and society, emerged during Andersen's time. ${ }^{10}$ Before 1814 , when Denmark lost Norway because of flawed military and foreign-policy decisions, this great European power was a multinational absolutist state consisting of the kingdom of Denmark, including the southern parts of presentday Sweden, plus the kingdom of Norway, the duchies of Schleswig and Holstein and some colonies in West Africa, East India and the West Indies. During the Napoleonic Wars and the wars resulting from the unification of Germany, Denmark lost most of its territories and almost all of its political power. The small size of the severed royal state allowed the emerging nation state to be heavily influenced in terms of politics, economy and culture by a numerous class of communitarian yet independent farmers and by a much smaller class of urban conservatives and liberals, many of whom worked as civil servants. As a result the small Danish nation state became very introverted, if not provincial, trying to make the best of its own small resources while building a strong open economy and a civic, nationally homogeneous society that later formed the basis of a strong welfare society. ${ }^{11}$

In the early twentieth century, Denmark embarked on a pragmatic politics of neutrality and sought close alliance with one of her previous enemies, the strong power to the south, Germany. With great difficulty Denmark remained neutral during the First World War. In the interwar years, Danish businesses, foreign service diplomats and others tried to open up Danish foreign policy to new economic and commercial interests, not least with respect to distant markets and to a more balanced link with Great Britain and the Western powers. But these 'internationalists' lost out to the pragmatic 'nationalists' who wanted to pursue a line of 'realpolitik', under which Danish national interests were best managed by maintaining close economic and political contacts with Germany. ${ }^{12}$

When Nazi Germany occupied Denmark on 9 May 1940, there was almost no resistance. The Danish government immediately surrendered and summarily began collaborating with the occupying forces. Formally, the politics of collaboration lasted until August 1943 and left Danish society relatively unscathed by the war, at least materially. Although there was some resistance to the Nazis, including the rescue of many Jews across the Sound to Sweden in October 1943, the ease with which Denmark allowed

10 U. Østergaard, 'Peasants and Danes: the Danish national identity and political culture', Comparative Studies in Society and History (1992), 34, 3-27; idem, 'Language and national identity in the Danish nationstate in the 19th century', History of European Ideas (1993), 16, 213-18; and idem, 'Denmark: A big small state - the peasant roots of Danish modernity', in National Identity and the Varieties of Capitalism: The Danish Experience (ed. J. L. Campbell, J. A. Hall and O. K. Pedersen), Montreal and Kingston, 2006, 51-98.

11 L. B. Kaspersen, 'The formation and development of the welfare state', in National Identity and the Varieties of Capitalism: The Danish Experience (ed. J. L. Campbell, J. A. Hall and O. K. Pedersen), Montreal and Kingston, 2006, 99-132.

12 B. Lidegaard, Defiant Diplomacy: Henrik Kauffmann, Denmark, and the United States in World War II and the Cold War, 1939-1958, New York, 2003. 
Nazi German occupation and the extent of politico-economic collaboration resulted in deep national feelings of guilt and shame. Along with the desire that Denmark escape the duck pond, so to speak, these feelings were very important in launching the Galathea Deep Sea Expedition.

\section{Forging scientific exploration with a national narrative}

Three of the most important organizers of the Galathea Deep Sea Expedition were the marine biologist Anton F. Bruun, the traveller and journalist Hakon Mielche and Vice-Admiral Aage H. Vedel. These men represented the three collaborative elements of the expedition: oceanographic science, the press and the Navy. They also shared a deeply felt wish to continue Denmark's expedition history, thus rehabilitating Denmark after the war. In late 1944 Bruun approached Vedel with the first written plan for the expedition. ${ }^{13}$ Bruun and Mielche had already been discussing the expedition for a few years. They had agreed that it was to be a circumnavigatory expedition and was to bring together deep sea research and real-time media coverage by including onboard a small press section reporting the expedition en route. Bruun, the zoologist and wellknown popularizer of marine biology, wanted to continue the Danish oceanographic tradition of Johannes Schmidt, Bruun's mentor and the leader between 1928 and 1830 of the Dana Expedition in which Bruun had participated. Mielche, the restless, travelling writer, was eager to resume his own travels around the world that had already entertained a national and international audience. ${ }^{14}$ Together, the two formed a creative partnership in organizing the collaboration between exploratory science and the media. ${ }^{15}$

For unknown reasons, in proposing the expedition to Vice-Admiral Vedel, Bruun did not mention his plans for a partnership with Mielche. He simply dealt with the scientific reasons for another Danish round-the-world deep sea expedition. He mentioned the fact that in the history of oceanographic expeditions, back to the British Challenger Expedition of 1873-6, the biology of the deep sea had remained largely unexplored. The physical features of the deep sea were comparatively well known. However, mainly due to inadequate fishing equipment, no large animals from depths below four thousand metres had ever been caught. Moreover, the geographical distribution of biological stations in the upper pelagic layers was very limited. All this called for an expedition exploring the deepest parts of the oceans using larger instruments than those normally employed in much shallower waters, continuing the Danish tradition of circumnavigation expeditions established by the first Galathea Expedition between 1845 and 1847 and by the Dana Expedition. Bruun topped his scientific narrative of the planned

13 Anton F. Bruun to Vice-Admiral Aage H. Vedel, 5 December 1944, Aa. H. Vedel Papers, the Danish National Archives, Copenhagen, No. 06499, Box 24.

14 H. Mielche, Monsunens sidste rejse, Copenhagen, 1935; and idem, Let's See if the World Is Round, London, 1938.

15 For essays on creative couples in the sciences see H. M. Pycior, N. G. Slack and P. G. Abir-Am, Creative Couples in the Sciences, New Brunswick, NJ, 1996. 
expedition by saying that by fishing the deep sea with larger nets and lines, one might possibly expect to capture large unknown animals such as the mythical sea serpent. ${ }^{\mathbf{1 6}}$

As the Second World War was drawing to a close, Bruun and Vedel met to discuss Bruun's plan. Like Bruun and Mielche, Vedel was quite sensitive to the fact that, after the war, Denmark would be in need of new initiatives and new national narratives to re-establish national confidence and international esteem. Having ordered the sinking of the Danish Navy after the showdown with the German occupation forces in August 1943, he also knew that the Navy would desperately need new vessels. Interestingly, the purchase of a new Danish vessel was an essential part of Bruun's original plan presented to the vice-admiral. Furthermore, Vedel took a personal interest in science and, more importantly, was highly influential through his position as director of the Ministry of Naval Affairs and head of the Operative Command of the Royal Danish Navy. ${ }^{17}$

Among the expedition planners, Hakon Mielche expressed himself most explicitly about the personal feelings of national remorse and dishonour that were an important part of the personal and national drive in organizing the expedition. In his first book about the expedition, he wrote,

To me, the adventure expedition was the vehicle for raising, after the war, as fast as possible, the national flag all around the globe.

In those years in many places there existed a somewhat skewed view of Denmark's position during the war. Those people, for whom the geographical and military conditions of Denmark were unknown, were wondering how Hitler was able to conquer Denmark as quickly and effortlessly as had been the case on 9 April 1940 .

...

But if, continuing the glorious tradition of Danish ocean research, we brought along an expedition vessel, and if this vessel was to sail around the Earth in pursuit of a scientific task so sensational that the world press was forced to take notice, then we would be able to put the flag in the spotlight again; Denmark would be the topic of conversation. Wherever the ship called at a port, films about Denmark, Danish nature, Danish culture, and Danish trades would be screened. And when the press embarked, surely, we would explain to them our scientific objectives, but at the same time tell them about the country that sent us, and what this country does when it is not dispatching scientific expeditions. ${ }^{18}$

The close link between the planning of the expedition and Danish experiences during the Second World War, as described by Mielche, became institutionalized in the Danish Expedition Foundation. This foundation raised funds in support of the Galathea Deep Sea Expedition and two other Danish scientific expeditions dispatched after the war, namely the Pearyland Expedition and the Third Central Asian Expedition. The total expenditure of the Galathea Expedition was 5.5 million Danish kroner (DKK; then approximately $£ 280,000)$, of which the Danish state financed three-quarters and the Expedition Foundation the balance. ${ }^{19}$ According to its statutes the foundation's purpose

16 On the role of the sea serpent in the expedition narrative see K. H. Nielsen, 'In search of the sea monster', Endeavour (2006), 30, 36-40.

17 S. Nørby, Flådens scenkning 29. august 1943, Odense, 2003.

18 H. Mielche, Galathea lagger ud, Copenhagen, 1951, 18. All Danish quotes have been translated by the present author.

19 R. Spärck, 'Background and origin of the expedition', in The Galathea Deep Sea Expedition 1950-1952 (ed. A. F. Bruun, S. Greve, H. Mielche and R. Spärck), London, 1956, 11-17. 
was to secure support 'for the inward and outward benefit of Danish science as well as Danish initiative and enterprise'. ${ }^{20}$ Its founders clearly believed Denmark's reputation needed a kind of resurrection, a new national narrative based on scientific exploration.

The Expedition Foundation originated from a meeting on 7 June 1945 in Hakon Mielche's home. Neither Bruun nor Vedel attended the meeting. The participants included three Danish explorers planning the two other expeditions to be funded by the Expedition Foundation: Ebbe Munck and Eigil Knuth (Pearyland), and Henning Haslund-Christensen (Central Asia). Also present was Mielche's friend Leif B. Hendil, chief editor of the newspaper Ekstra-Bladet, then known 'as the man who generates the money' ${ }^{21}$ In Danish history Hendil is best known for his illegal activities during the Second World War in providing passage for Jews across the Sound from Denmark to Sweden. He was very entrepreneurial and immediately took to Bruun and Mielche's idea of a combined science-media deep sea expedition. From his affiliation with the Danish resistance movement, he personally knew the other expedition planners, Munck, Knuth and Haslund-Christensen, and played an important role in bringing the three expeditions together in the Expedition Foundation.

The meeting in Mielche's home agreed to join forces by establishing the Danish Expedition Foundation to procure financial, political and moral support for the three expeditions. According to Mielche's recollection, Hendil came up with the idea of appealing for funding to Danes living abroad, since the embattled condition of the Danish economy forced the state and private foundations such as the Carlsberg Foundation to be much more reluctant in supporting scientific projects. Through personal contacts, Ebbe Munck, working in London as press attaché, disseminated the appeal. The Friends of Denmark in New York and the Danish community in the United Kingdom responded. Between 1945 and 1947 these groups provided the Expedition Foundation with a total of eight million American and British cigarettes. With approval from the Danish authorities, the cigarettes were sold on the Danish market as 'legal black market prizes', bringing in a total of 1.2 million DKK, amounting to approximately one-fifth of the total costs of the Galathea Deep Sea Expedition. ${ }^{22}$

In 1948, when the cigarettes had all been sold, and with the Munck-Knuth and Haslund-Christensen expeditions well under way, Hakon Mielche and Leif B. Hendil produced a pamphlet explaining 'to all Danes living abroad' what the Danish Expedition Foundation was all about, while also accounting for the financial requirements of the deep sea expedition. This expedition was to be much more expensive than the two others, and it was the only one still waiting to depart. Thus Mielche and Hendil appealed for fresh supplies of the special goods so much in demand in the home market: cigars, dried fruits, vanilla, nuts, pineapples, coconuts. They explained that by providing the foundation with such products, the benefactors were not only sponsoring the forthcoming round-the-world deep sea expedition but would also 'support Danish

20 Deed of Foundation for the Danish Expedition Foundation, May 1948, Danish Expedition Foundation, the Danish National Archives, Copenhagen, No. 10541, Box 1.

21 Mielche, op. cit. (18), 29.

22 Mielche, op. cit. (18), 30-1. 


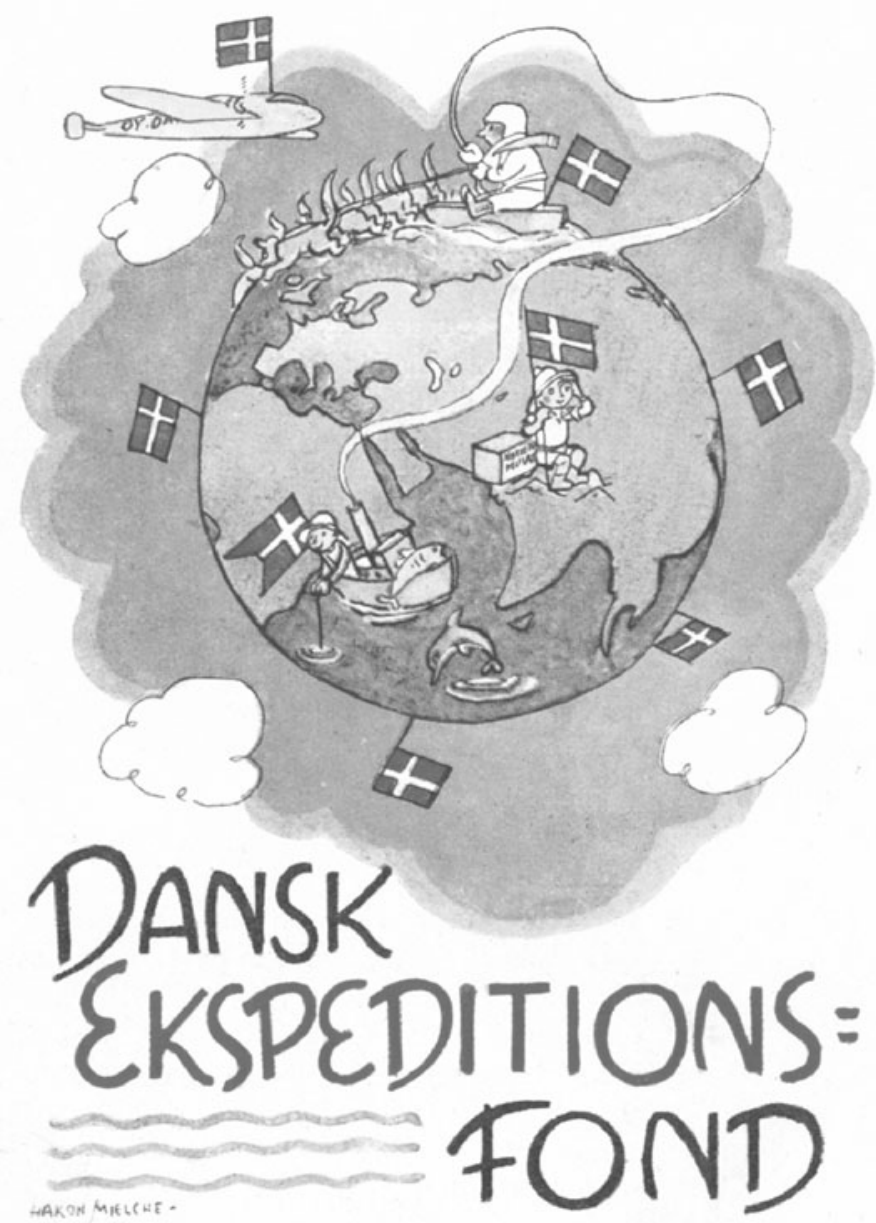

Figure 1. The frontispiece of Mielche and Hendil's pamphlet about the Danish Expedition. From H. Mielche and L. B. Hendil, 'Dansk Ekspeditionsfond', 1948, Commitee of the Danish Deep Sea Expedition, the Danish National Archives, Box 12. An ardent illustrator as well as a prolific writer, Mielche drew and authored most of the pamphlet, while Hendil took care to print the pamphlet free of charge and distribute it widely. Notably, even though collaboration between scientists and journalists formed a constitutive part of the Galathea Deep Sea Expedition, Mielche did not include the press in his illustration. The press, however, is present behind the scenes: press people, Mielche and Hendil, produced the postcolonial image of the three expeditions and Mielche authored the new national narrative about the expedition.

efforts to create a valuable reputation for the country all over the world, and the recognition thus created will benefit all Danes, at home and abroad'. ${ }^{23}$

The pamphlet's frontispiece clearly illustrated the message on behalf of the Expedition Foundation (see Figure 1). Given sufficient funding the foundation would take care to

23 H. Mielche and L. B. Hendil, 'Dansk Ekspeditionsfond', 1948, Committee of the Danish Deep Sea Expedition, the Danish National Archives, Box 12, quote from p. 2. 
dispatch three larger expeditions: Munck-Knuth on a combined sledge/airplane expedition to Greenland, Haslund-Christensen on a desert/mountain expedition to Central Asia, and Bruun and Mielche on their deep sea expedition. The three expeditions were all Danish scientific expeditions with an emphasis on the national narrative of Denmark as a scientific, peaceable, modern and internationally oriented nation state. All expeditions took care to wave, even to plant, the Danish flag worldwide. As a result, Danes would once again have 'conquered' parts of the world, in particular the world of science and the media, albeit in a very peaceful and almost scientific manner. In this sense, showing the flag through scientific exploration and extensive press coverage can be seen as the postcolonial equivalent of colonial display of the flag through warships and colonial science. ${ }^{24}$

\section{The scientific-national-naval-educational-media expedition narrative}

In 1947 Vice-Admiral Vedel and Anton Bruun approached the Ministry of Finance with a funding request for the expedition. The answer was negative, due to lack of public funds. Vedel engaged in intense lobbying in personal conversations with the prime minister, the minister of education and the minister of foreign affairs. In late 1948 the Finance Committee finally agreed to provide the funding necessary for the expedition. At a meeting in Vedel's office on 5 April 1948, the Committee of the Danish Deep Sea Expedition was established. Prince Axel, who was also involved in Danish resistance during the war and, after the war, had resumed working for the Danish East Asiatic Company (Østasiatisk Kompagni), agreed to head the committee, serving the expedition as an important, well-known advocate and figurehead. ${ }^{25}$

The appeal of the Expedition Foundation for supplementary support, made known widely through Mielche and Hendil's pamphlet, was well received. So the flow of goods and money from Danish expatriates continued. In early 1949 the planners of the deep sea expedition had the opportunity to purchase a suitable ship. The frigate Friendship was offered for sale by the World Friendship Association. The costs of converting the ship into a scientific expedition vessel enormously exceeded the original budget. The increased expenditures resulted in a considerable prolongation of the conversion work, primarily because an application for additional state funding turned out to be very difficult to accept on behalf of the Finance Committee. Thus the expedition was not ready to go until summer $1950 .^{26}$

At that time the main narrative of the expedition had more or less been settled. It drew on Danish naval and science history as well as postcolonial reconstructions of national geography and identity. In three interconnected unpublished papers, written in early 1950 when there was still some doubt as to whether the Finance Committee would grant extra funds for the expedition, the zoology professor Ragnar Spärck,

24 MacLeod, op. cit. (2); Schiebinger et al., op. cit. (2).

25 Minutes of the Committee of the Danish Deep Sea Expedition, 5 April 1950, Committee of the Danish Deep Sea Expedition, the Danish National Archives, Copenhagen, No. 10289, Box 1.

26 Minutes of the Committee of the Danish Deep Sea Expedition, 21 May 1948 and 26 October 1948, Committee of the Danish Deep Sea Expedition, the Danish National Archives, Copenhagen, No. 10289, Box 1. 
Vice-Admiral Vedel and Anton Bruun summed up the many different motives for embarkation on a Danish round-the-world deep sea research expedition. They argued that there were at least four main reasons for support from Denmark, the Danish state and the Danish people for the expedition.

First, the three authors all agreed that the main purpose of the expedition was science, first and foremost deep sea research, but also other forms of biological and oceanographic research and, to a much smaller extent, ethnography. Spärck wrote that 'when Danish scientific circles have supported this expedition so strongly, it is because of ocean studies being a field in which, particularly, Danish scientists have contributed and in which Danish science has great traditions that it seems natural to continue'. He mentioned a lineage of famous Danish scientists who, in his interpretation, had all made pioneering contributions to the understanding of marine biology. These were Otto Fr. Müller (1730-84), the first to carry out systematic collections of sea animals; Japetus Steenstrup (1813-97), first to organize systematic surveys in the pelagic regions; A. S. Ørsted (1816-72), first to recognize the vital importance of plankton as source of nutrition; and J. G. Forchhammer (1794-1865), discoverer of the chemical composition of seawater. The historical accuracy of such claims need not concern us here. Important is that they constitute a lineage of something like historical necessity in favour of more ocean exploration by Danish scientists. Spärck, of course, also listed previous Danish scientific expeditions in support of the new deep sea expedition. In particular, the expeditions led by Johannes Schmidt, most notably the Dana Expedition from 1928 to 1930, and the Danish Ingolf Expeditions in the North Atlantic in 1895 and 1896, testified to the need for another Danish ocean research expedition. If this Danish tradition of sound science and cutting-edge ocean exploration was to continue, there was need for another large-scale expedition with the participation of both experienced and younger scientists. ${ }^{27}$

Second, the expedition had important national tasks to fulfil. Even if, unlike Mielche, neither Spärck, Vedel nor Bruun explicitly referred to Denmark's bad reputation and lack of national self-worth after the Second World War, it was clear from their papers that the expedition would set out on an extraordinary national campaign. They argued that the expedition served many national objectives. In Spärck's view 'the expedition will contribute to knowledge about Denmark, Danish culture and Danish industry by featuring - wherever the expedition arrives-lectures and films about Denmark'.28 Vice-Admiral Vedel elaborated Spärck's statement by saying that the expedition would pay official visits to all local authorities. Moreover, the expedition would visit all previous Danish colonies in Africa, East India and the West Indies and make the widest contact possible with Danish expatriates. Vedel also explained that the Danish Ministry of Foreign Affairs had requested that the expedition disseminate information about Danish industry to cultivate new export markets. Especially because of the Danish fishing equipment brought with the expedition and because of Anton Bruun's many years of service in the Danish Fisheries Research Commission, which gave him

27 R. Spärck, 'Den danske dybhavsekspeditions videnskabelige baggrund og formål', 1950, Committee of the Danish Deep Sea Expedition, the Danish National Archives, Copenhagen, No. 10289, Box 1.

28 Spärck, op. cit. (27). 
extensive knowledge about fisheries in Danish waters and in the North Atlantic, the expedition would stand a good chance of promoting Danish fishing industries and trade. Vedel concluded that, within the limits provided by the primary objective, the expedition 'will strive to serve all Danish national and trade interests as adequately as possible'.29

Third, the Danish Navy had good reasons to participate in the expedition. The renovated ship alone would be a welcome addition to the naval fleet. Besides, considering the long dormancy of the Danish Navy, the training acquired by the ship's officers and recruits on an international expedition was very valuable and encouraging. The showing of the Danish flag all around the world, east of Suez in particular, would be of great symbolic value to the Navy. This had not happened since the first Galathea Expedition in $1845-7 .{ }^{30}$ It is interesting to note that, like that of Spärck, Vedel's narrative connected the expedition with Danish history in support of the national and naval objectives of the expedition. Apart from the first Galathea Expedition, an obvious reference point for both writers, Vedel mentioned the early twentieth-century Danish Valkyrien Expeditions that had also served to show the flag in different parts of the world. Even though the Valkyrien Expeditions had no scientific objectives and the first Galathea Expedition only had minor and largely unfulfilled scientific aspirations, they could both be listed as historical evidence of the Danish expedition tradition that so much needed continuation after the Second World War. ${ }^{31}$

Fourth, and last, the expedition narrative included considerations of public information and education. The press section was to record short films for Danish Culture Film (Dansk Kultur Film), a private institution established by the pedagogue Thomas P. Hejle to produce educational films offering information about and propaganda for Denmark and Danish industry. The press section would also produce radio shows for national broadcasting, 'benefiting national information and education on foreign countries and continents'. ${ }^{32}$ In many ways, the immediate post-war era appeared to most Danes to be a time of opening up towards the world beyond Denmark and Germany, and, surely, the scientific deep sea expedition was a means of signalling openness and achieving this new broader geographical view.

In the narrative produced by Professor Spärck, Vice-Admiral Vedel and Anton Bruun, the role of the press section was played down. However, the press section made up the fifth element in the expedition narrative alongside the scientific, national, naval and educational aspects. The reasons for including press and information services in the expedition were developed by Hakon Mielche in several books and articles. He argued that the press really tied together many of the scientific and the national objectives of the expedition. It was the press section that was to distribute stories about Denmark

29 Aa. H. Vedel, 'Søværnets deltagelse i dybhavsekspeditionen og ekspeditionens nationale opgaver', 1950, Committee of the Danish Deep Sea Expedition, the Danish National Archives, Copenhagen, No. 10289, Box 1.

30 Vedel, op. cit. (29).

31 M. Sterll, 'Galatheas rejse omkring jorden', in Natur, Nytte og And 1730-1850. Dansk Naturvidenskabs Historie (ed. H. Kragh), 2 vols., Århus, 2005, ii, 428-37.

32 Spärck, op. cit. (27). 
as widely as possible through press releases, films, lectures, radio shows, receptions and other media. The press section was to produce photographs as well as sound and film recordings for the scientists. The press was to communicate the scientific results at home and abroad ${ }^{33}$ For Mielche the press section was certainly 'a new approach' in that it saw 'the beginning of cooperation between the curious man in the street and the scientists', and thus served to connect all Danes to the scientific endeavour : ${ }^{34}$

The man in the street has earnt his passage. He is sending representatives of the three cultural media from which he gets his knowledge of events - radio, film and the press ... The man in the street will be able to follow the day-to-day progress of the expedition in telegrams to the daily press reporting the arrival at and departure from ports with exotic names that will intrigue his imagination. ${ }^{35}$

And so, with combined funding from the state and from the Expedition Foundation, and with the overarching, fivefold and complex expedition narrative in place, on 15 October 1950 the Galathea Deep Sea Expedition set out in search of new knowledge about the deep sea, publicity and new national narratives. Indeed, strong national sentiments marked the departure. The newspaper Berlingske Tidende reported that 'a great Danish achievement is to be accomplished' and Prince Knud telegraphed his best wishes to the captain, demanding that the expedition would 'wave the flag in honour of our old country Denmark', ${ }^{36}$

As the ship lay off the quay, the speakers played Hans Christian Andersen's patriotic tune, 'Denmark, My Native Land', sometimes regarded as a kind of unofficial national anthem. Andersen first wrote the poem in 1848-50 during the First Schleswig War, in which the central Danish government fought rebels in the duchies of Schleswig and Holstein. Under the influence of Danish victories, Andersen expressed optimism about the restoration of Danish glory through natural beauty and hard labour: 'A tiny land, but in the world you tower!' ${ }^{37}$ Interestingly, Andersen's friend Hans Christian Ørsted, a well-known physicist and chemist, confronted Andersen for not taking into account Danish scientists in his praise of all things Danish. In his autobiography Andersen explained that Ørsted sent him an additional stanza about 'Danish minds' from which emerged the 'daggers of thoughts' that have 'enlightened the whole wide world'. ${ }^{38}$ Although today Ørsted's additional stanza is virtually unknown, the planners and most of the people present at the departure of the Galathea Deep Sea Expedition would probably have celebrated Ørsted's inclusion of science and enlightenment as integral parts of the national narrative about Denmark and Danish national identity.

33 Mielche, op. cit. (18), 31-2.

$34 \mathrm{H}$. Mielche and A. F. Bruun, 'Science and the man in the street: A deepsea expedition round the world', Danish Foreign Office Journal (1950), 14-18, 17.

35 Mielche and Bruun, op. cit. (34), 17.

36 Tikili., 'Galathea drog i gaar ud i verden', Berlingske Tidende, 16 October 1950, 1.

37 H. C. Andersen, 'Denmark, My Native Land', 1850, available at http://www.andersen.sdu.dk/ rundtom/borge/danmark_e.html, accessed 24 November 2008.

38 H. C. Andersen, Mit livs eventyr, Århus, 1966 (1855). 


\section{Postcolonial encounters}

Based on surveys of national history and national identity, the historian Uffe Østergaard concludes that there is a fundamental discontinuity in Denmark's history, from the expansive, multinational, composite kingdom before the early nineteenth century to the nation state that emerged in the later nineteenth century: nationalist, largely rural until the mid-1950s and, except for Greenland and the Faroe Islands, extremely homogeneous. ${ }^{39}$ It was this latter, postimperial nation that submitted to German hegemony, ultimately opting for cooperation with the Nazi forces. Like Ørsted's addition to Andersen's poem, the scientific-national narrative at the heart of the Galathea Deep Sea Expedition aimed at reconstructing this historical rupture between a great past and current diminution. By means of science and scientific exploration this small nation state, with its tarnished reputation, would rise again and achieve a new kind of modern, postcolonial significance in the emerging, post-war world.

In the abridged, English translation of his three books about the expedition, Hakon Mielche connected deep sea research with postimperial aspirations to conquer international attention:

There will soon be no white patches left on the map of the world ... Civilization has already touched them, whether it be in the form of government patrols, men prospecting for gold or oil, or of scientific expeditions ... Every place is mapped; the great powers have raised their flags on even the most distant outposts, are quarrelling about uninhabited rocks, and apparently are almost ready to go to war over some isolated ice field. A contemporary Rider Haggard would have nowhere in which to site the land of Ophir, and zoologists can no longer dream of finding a prehistoric giant Saurian roaming the forests of Congo.

Now, two thirds of the globe's surface is covered with water, and of that water half lies at depths greater than 2,166 fathoms. Much of that is unknown territory, as unknown as America was before Columbus. Galathea, we hoped, was to be a Santa Maria of the sea. We were to be the first in the world to lower our fishing tackle to depths of 4,333 to 5,333 fathoms. ${ }^{40}$

In recalling the age of discovery, Mielche drew on well-known colonial narratives about conquest and civilization. However, at the same time he seemed to be making a distinction with the postimperial expectations of the Galathea Expedition. This expedition would entail no territorial conquest or commercial exploitation. It was all about conquest of the world of deep sea oceanography by becoming the first to probe the biology of the ocean's deepest parts. The expedition journeyed in the name of science, raising the flag of knowledge around the world. Despite its smallness, by means of the expedition Denmark would once again have a place among the leading nations. Denmark would have taken another step on the path to modernity.

Like Danish oceanic science, Denmark's colonial experiences bore evidence to the international importance of the nation. Denmark had played a minor role in Western

39 Perhaps expressed most clearly in U. Østergaard, 'Danish national identity: between multinational heritage and small-state nationalism', in Denmark's Policy towards Europe after 1945: History, Theory and Options (ed. H. Branner and M. Kelstrup), Odense, 2000, 139-84.

40 H. Mielche, Round the World with Galathea, London, 1954, 4-5. 
colonization and, moreover, had emerged from its colonial past with the image of being the first nation to abandon slavery. Public criticisms of this humanistic self-image did not really emerge until well into the 1960s with the publication of author Thorkild Hansen's three novels about the history of Danish slavery, the so-called Slave Trilogy. ${ }^{41}$ Thus Hakon Mielche was able to exploit Galathea's encounter with Denmark's previous colonies by promoting the fresh national narrative that formed part of the expedition's ideological baggage. It was a way in which to emphasize historical continuity (despite the rupture identified by Uffe Østergaard and other historians) and also to demonstrate the ancestral dimensions of the nation as an imagined community by establishing connections with Danes living abroad.

The expedition visited previous Danish colonies on the Gold Coast in West Africa, in the East Indies and in the Antilles. On the first half of the circumnavigation of the Galathea Expedition, from Denmark south to the Cape of Good Hope, then eastward heading towards the deep trenches in the Indian and the Pacific oceans, little happened in terms of deep sea research. So Mielche used the postcolonial encounters on the Gold Coast, once including Danish Guinea, now roughly present-day Ghana, to attract public interest in the expedition and its narrative about Denmark's past, present and future.

On 22 November 1950 the expedition called at Accra. For three consecutive weeks the weekly magazine Illustrated Family Journal (Illustreret Familie-Journal) featured Mielche's articles from the former Danish colony. In his first article Mielche recounted the history of the colony with a special emphasis on Danish involvement. Noting that there seemed to be a generally positive attitude towards Denmark and the Danes, he underscored the 'historical fact' that Danish slave traders 'merely acted as intermediaries between the Portuguese, the Spanish, the Arabs and unscrupulous Negro chiefs'. Moreover, he stressed that 'by 1792, Denmark had reached the point of humanism which led the Danish government to abolish the slave trade by 1801'. He also mentioned that, notwithstanding the horrors of slavery, Western colonization did bring the Gold Coast Western medicine, education and economic wealth. Signs of modernity, these elements were prerequisites for 'the changing times on the Gold Coast' that led Mielche to conclude that 'Having slept over millennia, the huge, black Africa now is stretching its limbs. ${ }^{42}$

Mielche's vision for postcolonial Africa was somewhat modified by his later remarks on the ability of Africans to wake up to democracy and economic responsibility. As one of the ways in which to disseminate national propaganda, in all ports at which the expedition called it was standard procedure that Mielche would present a film about Denmark, thus also in Accra. The film combined romantic images of snow-covered Copenhagen with an emphasis on the rise of Denmark as an industrial and scientific nation. Observing those Africans of importance who had been invited, Mielche

41 Stecher-Hansen, op. cit. (7).

42 H. Mielche, 'Galathea besøger Danmarks gamle besiddelser paa Guldkysten', Illustreret FamilieJournal, 20 February 1951, 4-5, 18. All quotes from 18. 
reported that they all became very drunk at the reception and quickly fell asleep during the show. Sarcastically, Mielche noted, 'Let's hope that the new-born democracy doesn't rest too heavily on their shoulders. After all, there are representative duties affiliated with democracy. ${ }^{43}$

The postcolonial appropriation of Denmark's colonial affiliations with Ghana for publicity purposes provided Mielche with a chance to extend the national narrative promoted by the expedition even further. Prince Axel, leader of the expedition's committee, but also an employee of the East Asiatic Company, joined the expedition in Accra. The company was interested in the country's forestry, which led Mielche to observe that 'Danish efforts again are felt on the Gold Coast':

A dash of sweat and sawdust, of noisy machines under Danish command, and of modern Danes making a difference in the contemporary history of the Gold Coast is highly refreshing. It proves that we haven't been entirely knocked out by the perpetual complaint about Denmark being a small nation that once was great, but no longer is capable of anything. ${ }^{44}$

There are at least two, not entirely mutually coherent, implications to be drawn from Mielche's reports. Firstly, Mielche's writings provide some evidence that, in 1950, to the travelling reporter on a scientific expedition, the postcolonial ideology of science and industry equalled Western modernity and civilization. In this sense, there are no radical discontinuities between colonial and postcolonial science. Surely, Mielche and his fellow expedition members would not have subscribed to the idea that their expedition marked any kind of break in the history of modern science. Their repeated insistence on their character as bearers of the tradition of Danish oceanography testifies to the opposite. The deep sea research conducted by the Galathea Expedition was a way of enacting modernity by means of the production of scientific knowledge and media coverage, even though the new territory to be conquered by Western science and media was far below the surface of the sea.

Secondly, there is a historical discontinuity implied by Mielche's enthusiasm about 'modern Danes' making a difference in the contemporary history of the Gold Coast. Extending the imagined community of Denmark to its previous colonies and other places, the Galathea Expedition, much like Danish companies, not only was the sign of modernity but also marked the fact that Denmark was rising above provincialism and peasantry and thus regaining its former greatness. In Mielche's rendering of the national narrative, through industry and science Denmark was throwing off the yoke of its long subjugation to other powers, in particular Germany. The Galathea Expedition presented itself as yet another way of 'drawing the attention of foreign countries to the small nation, which in a time where everybody is talking about cold war, and where hostility and fanaticism are spreading like the plague, has made a peaceful contribution to the benefit of all countries and is promoting understanding between the peoples of the world'. ${ }^{45}$

43 H. Mielche, 'Christiansborg', Illustreret Familie-Journal, 27 February 1951, 4-5, 22.

44 H. Mielche, 'Fra negerslaver til kakao', Illustreret Familie-Journal, 6 March 1951, 4-5, 28-9, 29.

45 Mielche, op. cit. (18), 7. 


\section{Scientific internationalism combined with foreign policy}

It would be wrong to construe the narratives produced by members of the Galathea Expedition as entirely national. On the contrary, narratives drawing out the international and even internationalist aspects of the expedition were always very forceful, supplementing and supporting the national narrative. In his unpublished paper of early 1950, cited above, Professor Ragnar Spärck accentuated the importance of the expedition in terms of international cooperation. He stressed the formation of international relations with the many foreign scientists that it was planned would take part in the expedition for longer or shorter periods. He also anticipated that the scientific results of the expedition would arouse interest internationally. ${ }^{46}$ Thus the Galathea Expedition was expected to wave not only the Danish flag, but also the international flag of science, in particular oceanography, all around the world. In so doing, the expedition would be reconstructing the internationalist narrative tying the oceanographic community more closely together.

Torben Wolff, zoologist and second in command of the scientific section of the Galathea Expedition, clearly saw the expedition as a fresh start to the internationalist aspirations of oceanography in the immediate post-war period:

When frontiers are closed scientific research stagnates. We had a good example of this in Germany during the Nazi regime, and even in Denmark the five years of occupation imposed limits on free research. No science can thrive without foreign contacts. And oceanography, concerned with the physical conditions of the oceans, their flora and fauna, and the utilization of these for the benefit of hungry man, is surely one of the most international of all the sciences. The sea affects us all, at once separating and uniting us; and practically every civilized nation has made its contribution, large or small, to its exploration. ${ }^{47}$

Internationalism in marine science had been on the agenda of many ocean explorers since the formation of the International Council for the Exploration of the Sea in 1902.48 After the Second World War oceanographic internationalism became much more strongly coupled to international policy-making and ocean research expanded dramatically. In his book on the international focus of American oceanography during the Cold War, the historian of science Jacob Darwin Hamblin shows how oceanographers made the most of the political strategy of containment promoted by the Truman administration immediately after the war. The Truman Doctrine included large-scale government-sponsored scientific programmes as a means of expansionist American foreign policy. For more or less the same reasons as those put forward by Torben Wolff, American oceanographers were able to situate marine science in the pursuit of international cooperation while also promoting American oceanographic institutions. Like Wolff, in public they often coupled scientific internationalism to scientific and technical developments abroad and at home. ${ }^{49}$ Some oceanographers

46 Spärck, op. cit. (27).

47 T. Wolff, 'Contact with international science', in The Galathea Deep Sea Expedition 1950-1952 (ed. A. F. Bruun, S. Greve, H. Mielche and R. Spärck), London, 1956, 272-81, 272.

$48 \mathrm{H}$. Rozwadowski, 'Internationalism, environmental necessity, and national interest: marine science and other sciences', Minerva (2004), 42, 127-49.

49 J. D. Hamblin, Oceanographers and the Cold War: Disciples of Marine Science, Seattle, 2005. 
clearly acknowledged the relationship between the emergence of new American foreign policies and the expansion of oceanography. They included marine geologist Robert S. Dietz, who in a letter to the director of the Scripps Institution of Oceanography observed that "the time has come when a "showing of the flag" can be more effectively done in parts of the world by a vessel engaged in scientific pursuits than by a man o'war'.50

The end of the Second World War also marked an abrupt change in Danish foreign policies. Before and during the first part of the war, Denmark had striven to remain neutral while also seeking close collaboration with Germany. After the war, Danish politicians recognized the need to become internationally engaged. In so doing, during the Cold War Denmark balanced full ideological alignment with the West and a more pragmatic policy of adaptation to a world dominated by two superpowers. A founding member of the United Nations (UN) in 1945 and the North Atlantic Treaty Organization (NATO) in 1949, Denmark embarked on the new internationalist path that also included seeking closer European integration and more Nordic cooperation. ${ }^{51}$

One of the first major challenges to the new internationalist aspirations in Danish foreign policy was the call for participation in the UN intervention in the Korean War. In summer of 1950 the Danish government received two inquires from the UN about possible assistance. Through the chief surgeon Karl Lehmann, it was agreed that Denmark would equip a hospital ship, Jutlandia, manned by Red Cross personnel. In spite of great financial difficulties, the government decided to let the international commitments of Denmark carry weight. Significantly, the Danish contribution to the international intervention was humanitarian and civil. ${ }^{\mathbf{2}}$

In terms of internationalist foreign policy, the Galathea Expedition was perceived as a scientific equivalent to the Jutlandia Expedition. In July 1951, in the midst of heated public debate about whether to grant the Galathea Expedition additional government funding to complete its circumnavigation, Anders Georg, serving as press officer of the Jutlandia, argued that, like Jutlandia, Galathea was 'Denmark's sailing ambassador'. Referring to Jutlandia and Galathea as 'Goodwill-ambassadors', Georg argued that the case against extra funding for the Galathea Expedition was petty and short-sighted. $\mathrm{He}$ stressed that

besides the tasks given, 'Galathea' - like 'Jutlandia' - is doing a significant job in representing Denmark abroad. The Danish colonies are crowding around the two ships, and isn't it just natural that our countrymen feel a little proud by showing to their foreign friends what their mother country is capable of and what she represents in international affairs $?^{53}$

Anders Georg gave Hakon Mielche and his press section most of the credit for the huge impact of the expedition in terms of publicity and goodwill.

50 Cited in J. D. Hamblin, 'Visions of international scientific cooperation: the case of oceanic science, 1920-1955', Minerva (2000), 38, 393-423, 393.

51 T. B. Olesen and P. Villaume, I blokopdelingens tegn 1945-1972. Dansk udenrigspolitiks historie, Copenhagen, 2006.

52 K. K. N. Midtgaard, Jutlandia-ekspeditionen: Tilblivelse og virke 1950-53, Copenhagen, 2001.

53 A. Georg, 'Galathea som Danmarks sejlende ambassadør', Berlingske Tidende, 19 June 1951, 5. 
To promote the new foreign policy based on international cooperation, humanitarianism and civil engagement that gradually emerged after the war, the Danish Ministry of Foreign Affairs took a keen interest in the Galathea Expedition. In 1948, upon request from Prince Axel, the ministry's director (and member of the resistance during the war) Frantz Hvass agreed to represent the ministry in the Committee of the Danish Deep Sea Expedition because of 'the national interests, internal as well as external', that were attached to the expedition. ${ }^{54}$ When, with the purchase of the ship in 1949 , the expedition really began to take shape, the Trade Office of the ministry appealed to the expedition planners to carry different materials relating to Danish industry, in particular the fishing industry. The material was to be used in fulfilling the second objective of the expedition, national flag-waving. When calling at foreign ports, the expedition, in collaboration with local Danish representatives, was to disseminate the information as widely as possible and thus further Danish export interests. ${ }^{55}$

Anton F. Bruun, among others, welcomed the opportunity to promote the Danish fishing industry. He certainly acknowledged the fact that ocean research was important, if not decisive, in the development of industrial fishing. Responding to the call of the Ministry of Foreign Affairs, he pointed out that the expedition was already keenly awaited in Chile, Peru, New Zealand, Australia and other places in which deep sea fishing played a significant role. Moreover, he stressed that the fish-master of the expedition was an experienced industrial fisherman, that the fishing implements used by the expedition were more or less all used by the Danish fishing fleet, and that the deepfreezer installation was made in Denmark. He therefore strongly believed that the expedition would be able to promote the Danish fishing industry in the manner proposed. ${ }^{\mathbf{5 6}}$

As a result, in many foreign ports and in close collaboration with local Danish representatives, the expedition made an effort to meet local fishing authorities and demonstrate Danish capabilities in fishing. For instance, after the expedition had called at Calcutta between 27 April and 1 May 1951, the Royal Danish Embassy reported that the visit

provided several opportunities to give useful 'backing' to the Danish enterprise behind the Government of West Bengal's fishing scheme and it was gratifying to notice the alertness with which Dr. Baini Prasad, Government's Fisheries Adviser, seized every opportunity the visit offered to push his expansion plans and other related fisheries projects. For him and the Secretary for Fisheries, Mr. S. I. Day, who both were in Denmark last year to purchase the two

54 Prince Axel to Minister of Foreign Affairs Frantz Hvass, 13 April 1950, Committee of the Danish Deep Sea Expedition, the Danish National Archives, Copenhagen, No. 10289, Box 2; Frantz Hvass to Prince Axel, 15 April 1950, Committee of the Danish Deep Sea Expedition, the Danish National Archives, Copenhagen, No. 10289, Box 2.

55 Trade Office of the Ministry of Foreign Affairs of Denmark, 'Notat til Komiteen for den Danske dybhavsekspedition', 29 October 1949, Committee of the Danish Deep Sea Expedition, the Danish National Archives, Copenhagen, No. 10289, Box 2.

56 A. F. Bruun, 'Verdrørende notat fra Udenrigsministeriets Handelskontor', 22 November 1949, Committee of the Danish Deep Sea Expedition, the Danish National Archives, Copenhagen, No. 10289, Box 6. 
Danish fishing vessels, the visit no doubt meant a considerable help, not least because the Danish fishing scheme is very much in the limelight in Calcutta and therefore during the visit became a frequent matter of discussion at high levels. ${ }^{57}$

In many other countries, including the Philippines, New Guinea, Australia, New Zealand and Mexico, efforts to the same effect were being made. ${ }^{58}$ According to the original plan, the expedition was supposed to have paid a similar visit to Japan. Due to delays, however, the visit had to be abandoned. The cancellation led the director of the Danish diplomatic mission in Tokyo, L. Tillitse, to express grave concern about the opportunities missed, particularly since meetings with the Fisheries College of Tokyo, the Japanese Society of Scientific Fisheries and the Society of Scientific Oceanography had already been arranged. On this matter, Tillitse collaborated closely with the Supreme Commander of the Allied Forces (SCAP), who believed that economic development could not only democratize Japan but also prevent the re-emergence of militarism, and counter communism in the Land of the Rising Sun. ${ }^{59}$ As a result, the Ministry of Foreign Affairs urged the Committee for the Danish Deep Sea Expedition to alter the navigation route so as to accommodate the highly important visit to Japan. ${ }^{60} \mathrm{In}$ the Danish press, it was reported that the visit would not only have helped inspire Danish firms to establish branches in Japan, but also have served the Japanese people in reconstructing their country. ${ }^{61}$

As an instrument of Danish foreign policy, the Galathea Expedition demonstrated that it was possible for a small country like Denmark to engage internationally on the basis of scientific exploration, perceived as an objective and civilizing means of advancing scientific and technological progress all over the world. The Galathea Expedition thus used the new internationalist dimension that was gaining acceptance within Danish foreign policy to strengthen the national narrative about the expedition: Denmark once might have been small, insignificant and inward-looking but now, however, because of her tradition of scientific exploration and her humanitarian outlook, Denmark was ready to make a difference in the emerging international order. Denmark, so the Galathea Expedition showed, was no longer Hitler's little canary. Scientifically and politically, Denmark was making a difference in the world beyond the duck pond.

57 The Royal Danish Embassy of India, 'Report on the visit of H.M.S. Galathea to Calcutta', 4 May 1951, Committee of the Danish Deep Sea Expedition, the Danish National Archives, Copenhagen, No. 10289, Box 6.

58 S. Greve, 'Skibet og togtet', in Galatheas jordomsejling 1950-52. Den danske dybhavsekspeditions virke og resultater skildret af deltagerne (ed. A. F. Bruun, S. Greve, H. Mielche and R. Spärck), Copenhagen, 1953, 11-38.

59 L. Tillitse to the Ministry of Foreign Affairs of Denmark, 7 May 1951, Committee of the Danish Deep Sea Expedition, the Danish National Archives, Copenhagen, No. 10289, Box 6.

60 Ministry of Foreign Affairs of Denmark to the Committee for the Danish Deep Sea Expedition, 29 May 1951, Committee of the Danish Deep Sea Expedition, the Danish National Archives, Copenhagen, No. 10289, Box 6.

61 top-, 'Minister Tillitse burde have hjælp', Berlingske Aftenavis, 22 May 1951, 3. 


\section{The discovery of deep sea fauna}

The Galathea Deep Sea Expedition of 1950-2 formed part of more or less interconnected and immediately post-war European efforts to conduct deep sea research. In 1947 a Swedish team led by Hans Pettersson embarked on the Albatross Deep Sea Expedition to take ocean bottom sediment cores. ${ }^{62}$ Pettersson's team used an innovative geological tool, a piston corer developed by Börje Kullenberg, and a winding gear designed to pull in very long lines. Both instruments were also used by the Galathea Expedition, in which three Swedish scientists, Kullenberg, Torsten Gislén and Oscar Nybelin, participated. Besides the two Scandinavian expeditions, the British Challenger II Expedition of 1950-2 also deserves mention. The Challenger II circumnavigated the globe primarily to conduct seismic refraction studies. In June 1951, approximately one month before the Galathea Expedition arrived at its most important destination, the Philippine Trench, the British expedition performed a first sounding of the Mariana Trench to find that it was slightly deeper than the Philippine Trench. After a second echo sounding in October, the British team was able to conclude with some national pride, 'It is a matter of high interest to have revealed that the greatest ocean depths exist in the Mariana Trench, and it is a particular pleasure to record that the discovery was made by a British naval vessel bearing the honoured name of Challenger. ${ }^{\mathbf{6} 3}$

Today the Galathea Deep Sea Expedition is best known for its contributions to the biology of the deep sea, in particular the discovery of a deep sea fauna and the catch of the live proto-mollusc Neopilina galatheae, which at the time was believed to have become extinct some 350 million years ago. On board the Galathea, American microbiologist Claude E. ZoBell grew barophile bacteria from sediment samples taken from the bottom of the Philippine Trench. ${ }^{64}$ From this trench, and from four other deep sea trenches in the Pacific and the Indian Oceans, were hauled numerous biological specimens proving that in the deepest parts of the oceans there is indeed life. Anton Bruun observed that the 'proof that a variety of animals have been adapted to life under a pressure of more than 10,000 atmospheres must lead to a renewed consideration of many problems in physiology and biochemistry'. ${ }^{65}$ Due to the extreme living conditions - eternal dark, low temperature and very high pressure - he suggested naming the deep sea ecological zone Hadal, derived from the word Hades, the realm of the dead in Greek mythology. ${ }^{66}$

The expedition is also known, though to a much lesser extent, for pioneering the strategic science-media partnership in scientific exploration. In his final report Hakon Mielche concluded that 'the information service was an innovation and like all infants we had our teething troubles'. Mielche referred to the adverse publicity that, shortly upon departure, his press section received in the Danish press where Mielche was

62 H. Pettersson, 'The Swedish Deep-Sea Expedition, 1947-48', Deep-Sea Research (1953), 1, 17-24.

63 N. Carruthers and A. L. Lawford, 'The deepest oceanic sounding', Nature (1952), 169, 601-3, 603.

64 C. ZoBell, 'Bacterial life at the bottom of the Philippine Trench', Science (1952), 115, 507-8.

65 A. F. Bruun, 'The Philippine Trench and its bottom fauna', Nature (1951), 168, 693.

66 A. F. Bruun, 'The abyssal fauna: its ecology, distribution and origin', Nature (1956), 177, 1105-8. 
accused of operating a press monopoly. ${ }^{67}$ Along the same lines, he also acknowledged that some scientists had been somewhat reluctant to bringing the press on board:

The inclusion in the Galathea Expedition of a public relations department to cater for the Press, films, and the radio was such a new departure in this kind of enterprise that it was bound to evoke a good deal of comment, not to say criticism, among scientists. To an older generation the word 'publicity' meant the ballyhoo associated with the showmanship of Barnum, which they saw perpetuated in the 'sensational discoveries' of the smart pseudo-scientific magazine articles of today. ${ }^{68}$

\section{Narratives as technologies of travel}

This paper has stressed the national and international narratives that were used in support of the expedition and mediated by the press and other media. The (inter)national narratives, along with narratives about scientific exploration, turned out to be important technologies of travel for the Galathea Expedition. They were crucial in securing the governmental and public support for the expedition that was necessary for such a relatively large Danish undertaking in terms of exploratory oceanography. They also played an important role in disseminating the knowledge produced by the expedition members to a much wider audience than otherwise would have been possible. The man in the street, to paraphrase Mielche, earnt his passage by means of these narratives and the media acted as his representative on the expedition, to the dissatisfaction of some scientists, mostly (according to Mielche) of the older generation.

With the dispatch of the Danish Galathea 3 Expedition (2006-7), which also combined scientific research with national narratives, extensive media coverage and educational information, in contemporary Denmark we still see the effects of this highly original effort. ${ }^{69}$ The Galathea 3 Expedition was conceived as a way to strengthen Danish science by means of increased funding to science and increased popularity of science among the younger generation. Similarly, the Galathea Deep Sea Expedition benefited from increasing interest in supporting science. The huge influx of private goods and money to the Danish Expedition Foundation shows that, after the Second World War, the general population shared this interest. The immediate post-war period also saw the rise of Danish research policies. In many ways, the Galathea Deep Sea Expedition became one of the first examples of Danish governments taking an active interest in supporting larger scientific projects. Before the war, scientific research in Denmark had mainly been sponsored by private foundations such as the Carlsberg Foundation and the Rockefeller Foundation. After the war, inspired by the British social relations of science movement and by the new linear model of science and technological innovation that emanated from the USA with the publication of Vannevar Bush's report to the president, Science, the Endless Frontier, Danish scientists and

67 Nielsen, op. cit. (4).

68 H. Mielche, 'Films, press, and radio on the expedition', in The Galathea Deep Sea Expedition 1950-1952 (ed. A. F. Bruun, S. Greve, H. Mielche and R. Spärck), London, 1956, 282-93, 282.

69 The Danish Expedition Foundation, 'Galathea 3', available at http://www.galathea3.dk/uk, accessed 14 November 2008. 
journalists began protesting against what, at the time, became known as the 'proletarianization of science' ${ }^{70}$ In February 1951, while the Galathea Expedition was well under way, more than five thousand scientists, students and others marched in the streets of Copenhagen to demand increased public support for science. As a result the government took steps to establish the State Common Science Foundation, simply known as the State Carlsberg Foundation. ${ }^{71}$ Along with added emphasis on research and development in Danish industries, this was yet another sign that by the early 1950s Denmark was emerging from its peasant roots to partake in technoscientific modernity. $^{\mathbf{7 2}}$

Portraying the expedition as a postcolonial partnership between science, media and (inter)national narratives, this paper in important ways supplements previous accounts about the Galathea Deep Sea Expedition and adds to general knowledge about postSecond World War scientific exploration in a postcolonial context. Much more than an oceanographic expedition, the Galathea Expedition also aimed at showing the flag by means of representative, scientific, naval, educational and media activities. The principal planners constructed a complex narrative about the expedition according to which the Galathea Expedition was conceived as a natural continuation of previous oceanic exploration expeditions dispatched from Denmark, but also as a way in which to construct a new national narrative. According to this narrative, Denmark had emerged from a neutral inward-looking past that had led to collaboration with the Nazis during the Second World War, to its condition as a nation promoting international scientific cooperation along with economic development and global media coverage. Endeavouring to become the postcolonial equivalent of Columbus, the Galathea Expedition sought to conquer new scientific ground while also seeking to improve the international image of Denmark and to position the expedition narrative as a national rallying point in the immediate post-war period.

The national expedition narrative fed on the gradual emergence of a new internationalist agenda in Danish foreign policy. Among the first signs of Denmark's new role in international affairs were its founding memberships of organizations like the UN and NATO and, in particular, the dispatch of the hospital ship Jutlandia in 1951, providing humanitarian aid to the UN intervention in the Korean War. The Galathea Expedition was another such example of Denmark's desire to engage internationally. At the time it had been the most international oceanographic expedition in terms of scientific participants from countries other than the country of origin. 'It is our hope, shared by all our guests, that with this idea we have established a tradition', wrote Torben Wolff. ${ }^{73}$ Until his sudden death in 1961, Anton F. Bruun for one continued to

70 K. H. Nielsen, 'Enacting the social relations of science: historical (anti-)boundary-work of Danish science journalist Børge Michelsen', Public Understanding of Science (2008), 17, 171-88.

71 H. Knudsen, 'Politik, penge og forskningsvilkår', in Viden uden granser. Dansk Naturvidenskabs Historie 1920-70 (ed. H. Nielsen and K. H. Nielsen), Århus, 2006, 323-46.

72 N. Thomsen, O. Hyldtoft, J. P. Christensen, H. C. Johansen, C. Nilsson and P. Boje, Dansk industri efter 1870. Industriens voekst og vilkår, 6 vols., Odense, 1988-97; and S. A. Hansen, Early Industrialisation in Denmark, Copenhagen, 1970.

73 T. Wolff, 'Contact with international science', in The Galathea Deep Sea Expedition 1950-1952 (ed. A. F. Bruun, S. Greve, H. Mielche and R. Spärck), London, 1956, 272-81, 272. 
pursue this line of international cooperation in oceanography. A leading and unifying figure in the international oceanographic community, he was active in the establishment of a number of international bodies such as the Scientific Committee on Oceanic Research, the International Advisory Committee on Marine Sciences, the International Association of Biological Oceanography, and the Intergovernmental Oceanographic Commission (IOC) under the UN. He served as the first chairman of the IOC in $1961 .^{74}$ In an obituary published in the journal Copeia, Carl L. Hubbs remembered Bruun as 'one of the world's leading ichthyologists, oceanographers, general biologists, and scientific statesmen'. ${ }^{75}$

Paraphrasing Hubbs, we may conclude that the Galathea Deep Sea Expedition was an important effort in deep sea research, but also a ship of state. It accomplished groundbreaking discoveries and its collections still form the basis of new research. ${ }^{76}$ It also was part of the new nation-building in terms of national pride, international reputation and foreign policies that engaged the Danish population after the war. When the expedition arrived at Copenhagen on 29 June 1952, three months early because of lack of funds, there seemed to be widespread agreement among the speakers that the expedition had succeeded scientifically and nationally. Speaking on behalf of the government and of the whole nation, the education minister Flemming Hvidberg stated, 'Dear Galatheans, we are all proud of the way in which you have waved the flag of Denmark all over the world, and we are even more proud that this flag now waves above the results of your research. ${ }^{77}$ The captain of the ship, Svend Greve, agreed. 'We all owe a lot to science', he said, and went over and shook Anton Bruun's hand firmly while adding, 'Everything we have done, our scientific research, our representative duties, we have done for Denmark. ${ }^{78}$

74 Hamblin, op. cit. (49); Rozwadowski, op. cit. (48).

75 C. L. Hubbs, 'Death notice: Anton Fredrik Bruun', Copeia (1962), 2, 481-2.

76 K. Baba, 'Deep-sea chirostylid and galatheid crustaceans (decapoda, anomura) from the Indo-Pacific, with a list of species', Galathea Report: Scientific Results of The Danish Deep-Sea Expedition Round the World 1950-52 (2005), 20, 1-317.

77 Anon., ‘30.000 københavnerne modtog Galathea', Politiken, 30 June 1952, 1.

78 Tikili., 'Straalende velkomst til "Galathea”, Berlingske Tidende, 30 June 1952, 1. 